\title{
Individualized Hemodialysis Treatment: A Perspective on Residual Kidney Function and Precision Medicine in Nephrology
}

\author{
Inkyong Hur ${ }^{a}$ b Yong Kyu Lee ${ }^{a, c}$ Kamyar Kalantar-Zadeh a, d, e \\ Yoshitsugu Obia \\ ${ }^{a}$ Harold Simmons Center of Kidney Disease Research and Epidemiology, Division of \\ Nephrology and Hypertension, University of California Irvine School of Medicine, Orange, \\ CA, USA; ${ }^{b}$ Nephrology Division, Department of Internal Medicine, Seomyong Christianity \\ Hospital, Pohang, South Korea; ${ }^{C}$ Nephrology Division, Department of Internal Medicine, \\ NHIS IIsan Hospital, Goyang, South Korea; d Nephrology Section, Tibor Rubin Veterans \\ Affairs Medical Center, Long Beach, CA, USA; eFielding School of Public Health at UCLA, \\ Los Angeles, CA, USA
}

\section{Keywords}

Hemodialysis - Residual kidney function · Precision medicine - Incremental hemodialysis .

Twice-weekly hemodialysis · Patient-centered outcome $\cdot$ Individualized treatment

\begin{abstract}
Background: Residual kidney function (RKF) is often expected to inevitably and rapidly decline among hemodialysis patients and, hence, has been inadvertently ignored in clinical practice. The importance of RKF has been revisited in some recent studies. Given that patients with end-stage renal disease now tend to initiate maintenance hemodialysis therapy with higher RKF levels, there seem to be important opportunities for incremental hemodialysis by individualizing the dose and frequency according to their RKF levels. This approach is realigned with precision medicine and patient-centeredness. Summary: In this article, we first review the available methods to estimate RKF among hemodialysis patients. We then discuss the importance of maintaining and monitoring RKF levels based on a variety of clinical aspects, including volume overload, blood pressure control, mineral and bone metabolism, nutrition, and patient survival. We also review several potential measures to protect RKF: the use of high-flux and biocompatible membranes, the use of ultrapure dialysate, the incorporation of hemodiafiltration, incremental hemodialysis, and a low-protein diet, as well as general care such as avoiding nephrotoxic events, maintaining appropriate blood pres-
\end{abstract}

I. Hur and Y.K. Lee contributed equally to this study. 
sure, and better control of mineral and bone disorder parameters. Key Message: Individualized hemodialysis regimens may maintain RKF, lead to a better quality of life without compromising long-term survival, and ensure precision medicine and patient-centeredness in nephrology practice.

(C) 2018 S. Karger AG, Basel

\section{Introduction}

Residual kidney function (RKF), even at such a low level that is usually observed among patients with end-stage renal disease (ESRD), substantially contributes to fluid balance and clearance of uremic toxins [1]. Due to its continuous nature, RKF has additional advantages over hemodialysis in mitigating dynamic changes in body fluid and facilitating the removal of middle molecules and protein-bound solutes [2-6]. RKF also plays a role in endocrine functions such as the production of erythropoietin and the activation of vitamin D [7]. Greater RKF among hemodialysis patients has been correlated with better nutritional status and lower mortality [7-11]. Additionally, patients with substantial RKF have a better quality of life in terms of social function, mental health, and cognitive function [7].

While routinely evaluated among patients on peritoneal dialysis in clinical practice, RKF has been underappreciated among hemodialysis patients. Rather, the adequacy of hemodialysis has been the primary focus of both research and clinical practice, since RKF was believed to go through inevitable rapid decline after the initiation of hemodialysis [1214]. However, the application of high-dose dialysis failed to show a survival benefit in the Hemodialysis (HEMO) study [15] and the deterioration rate in RKF among hemodialysis patients treated with high-flux biocompatible dialysis membranes and ultrapure dialysates was reported to be similar to that among peritoneal dialysis patients [16]. Therefore, we believe it is time to reevaluate the clinical importance of RKF among hemodialysis patients and to incorporate RKF levels in the management of hemodialysis patients. Indeed, a recent study revealed that plasma concentrations of secreted solutes (i.e., hippurate, phenylacetylglutamine, indoxyl sulfate, and p-cresol sulfate) can be well controlled by twice-weekly hemodialysis in patients with RKF [2]. Given that patients with ESRD now tend to initiate maintenance hemodialysis therapy with higher RKF levels, there seem to be important opportunities for incremental hemodialysis by individualizing the dose and frequency according to their RKF levels. This approach is realigned with precision medicine and patient-centeredness.

\section{How to Calculate Residual Kidney Urea Clearance}

Although RKF can be deduced simply based on self-reported urine volume, this does not precisely reflect RKF, partly because the urine volume is affected by many clinical factors such as fluid intake, diuretics, renal concentrating ability, and serum levels of urea and glucose. Hence, residual renal urea clearance $\left(\mathrm{CL}_{\mathrm{urea}}\right.$ or $\left.\mathrm{Kru}\right)$ remains to be the practical method for estimating RKF among hemodialysis patients because renal $\mathrm{CL}_{\text {urea }}$ can be incorporated into urea-based dialysis adequacy (i.e., $\mathrm{Kt} / \mathrm{V}_{\text {urea }}$ ).

However, estimating renal $\mathrm{CL}_{\text {urea }}$ has been challenging in clinical practice because it requires formal urea kinetic modeling using a specific software (i.e., Solute-Solver ${ }^{\circledR}$ ) to obtain the time-averaged serum urea nitrogen concentration during a urine collection [17]. There are some alternative methods such as an average of the pre- and postdialysis serum urea nitrogen concentrations, Jindal and Goldstein's equation, or multiplying a factor of 0.9 against 
Table 1. Available equations to estimate RKF

\begin{tabular}{|c|c|c|c|}
\hline Study [Ref.] & Feature & Pros & Cons \\
\hline \multicolumn{4}{|l|}{ Formal urea kinetics } \\
\hline Daugirdas et al. [17] & $\begin{array}{l}\text { Formal urea kinetics using a Web-based } \\
\text { software (Solute-Solver }{ }^{\circledR} \text { ) available at } \\
\text { www.ureakinetics.org }\end{array}$ & $\begin{array}{l}\text { The most precise method; } \\
\text { applicable to various } \\
\text { conditions }\end{array}$ & $\begin{array}{l}\text { Requires detailed } \\
\text { information input on } \\
\text { the website }\end{array}$ \\
\hline \multicolumn{4}{|c|}{ Estimating equations based on urine collection } \\
\hline $\begin{array}{l}\text { Conventional equation } \\
\text { (no original literature) } \\
{[18]}\end{array}$ & $\begin{array}{l}\text { Uses the average of the postdialysis } \\
\text { SUN before urine collection and the } \\
\text { predialysis SUN after urine collection }\end{array}$ & - & $\begin{array}{l}\text { Overestimates RKF by } \\
10.3 \% \text { on average }[21]\end{array}$ \\
\hline $\begin{array}{l}\text { Jindal and Goldstein } \\
\text { [19] }\end{array}$ & $\begin{array}{l}\text { Uses different factors for the } \\
\text { postdialysis SUN before urine collection } \\
\text { and the predialysis SUN after urine } \\
\text { collection in thrice-weekly versus } \\
\text { twice-weekly hemodialysis }\end{array}$ & - & $\begin{array}{l}\text { Underestimates RKF by } \\
9.9 \% \text { on average }[21]\end{array}$ \\
\hline Daugirdas et al. [20] & $\begin{array}{l}\text { A factor of } 0.9 \text { is used for the } \\
\text { predialysis SUN to estimate the } \\
\text { time-averaged concentration during } \\
\text { a urine collection }\end{array}$ & $\begin{array}{l}\text { Simple; does not require } \\
\text { postdialysis SUN }\end{array}$ & $\begin{array}{l}\text { Overestimates RKF by } \\
4.5 \% \text { on average, with a } \\
\text { larger error with less } \\
\text { frequent hemodialysis } \\
\text { [21] }\end{array}$ \\
\hline Obi et al. [21] & $\begin{array}{l}\text { Uses the predialysis SUN, the urea } \\
\text { reduction rate, and the duration of } \\
\text { urine collection and the interdialytic } \\
\text { interval }\end{array}$ & $\begin{array}{l}<5 \% \text { error in }>98 \% \text { of cases } \\
{[21] ; \text { applicable to various }} \\
\text { conditions }\end{array}$ & - \\
\hline \multicolumn{4}{|c|}{ Estimating equations based on serum markers } \\
\hline Shafi et al. [25] & $\begin{array}{l}\text { Uses } \beta \text {-trace protein, } \beta_{2} \text {-microglobulin, } \\
\text { and gender }\end{array}$ & \multirow[t]{2}{*}{$\begin{array}{l}\text { Does not require urine } \\
\text { collection }\end{array}$} & \multirow{2}{*}{$\begin{array}{l}\text { Relatively large errors; } \\
\text { assays are not widely } \\
\text { available; not suitable } \\
\text { for patients with } \\
\text { hemodiafiltration }\end{array}$} \\
\hline Wong et al. [26] & $\begin{array}{l}\text { Uses } \beta \text {-trace protein, } \beta_{2} \text {-microglobulin, } \\
\text { creatinine, predialysis SUN, gender, and } \\
\text { ethnicity }\end{array}$ & & \\
\hline
\end{tabular}

SUN, serum urea nitrogen; RKF, residual kidney function.

the predialysis urea, as suggested by Daugirdas (Table 1) [18-20]. However, all methods lead to biased estimation with wide variation in error depending on the duration of the urine collection period and the interdialytic interval. Recently, a new equation where the estimated $\mathrm{CL}_{\text {urea }}$ agrees well with the formal kinetic model-based values, with $<5 \%$ error in most clinical scenarios, was presented (Fig. 1) [21]. The European Best Practice Guidelines recommend using the estimated glomerular filtration rate, that is, the mean of urea and creatinine clearance based on the Casino and Lopes kinetic estimate, to be consistent with peritoneal dialysis practice $[22,23]$.

Nevertheless, 24-h urine collection is labor intensive, and it is difficult for many patients to adhere to its protocol and to collect all their urine during a specified period, which leads to biased estimates of their RKF. 


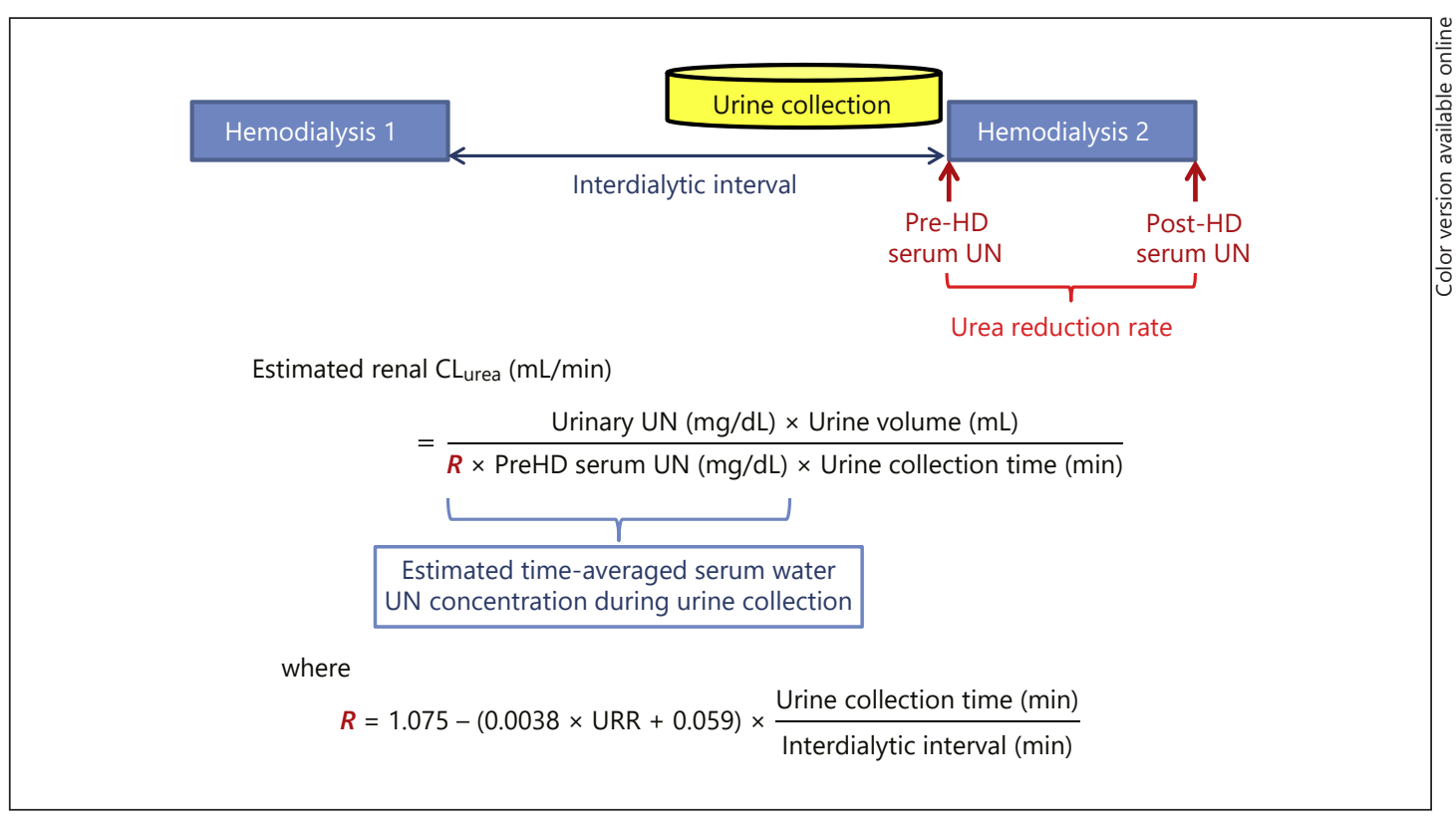

Fig. 1. How to estimate renal urea clearance $\left(\mathrm{CL}_{\mathrm{urea}}\right.$ or $\left.\mathrm{Kru}\right) . R$ is a factor for predialysis serum urea nitrogen (UN) to estimate the time-averaged serum water UN concentration during urine collection. The value of 1.075 in $R$ is simply $1 / 0.93$ and results from the need to correct the predialysis urea concentration for serum water. Urine collection is supposed to be completed $1 \mathrm{~h}$ before the subsequent dialysis treatment. HD, hemodialysis.

\section{Other Estimation Markers and Their Limitations}

There are other methods for estimating RKF using serum filtration markers, such as cystatin $C, \beta_{2}$-microglobulin, and $\beta$-trace protein. Serum cystatin $C$ (13.3 $\left.\mathrm{kDa}\right)$ is correlated with RKF among dialysis patients, but its utility is limited because of the large nonrenal clearance of cystatin C exceeding its renal clearance by RKF. $\beta_{2}$-Microglobulin $(11.8 \mathrm{kDa})$ is also removed by high-flux hemodialysis, and its concentration increases in patients with malignancy or inflammation [24]. In contrast, $\beta$-trace protein $(23-29 \mathrm{kDa})$ is not removed by conventional low- or high-flux dialysis and shows a steady concentration during the interdialytic period. Some authors suggested dialysis-specific equations using these markers, showing a good correlation with measured RKF $[25,26]$. It is useful and convenient to estimate RKF without collecting 24 -h urine and to identify those patients with $\mathrm{CL}_{\text {urea }} \geq 2.0 \mathrm{~mL} / \mathrm{min} / 1.73 \mathrm{~m}^{2}$. However, the equation was developed with cross-sectional estimation and, hence, was not fully validated for repeated measurements over time. Indeed, in the study by Shafi et al. [25], the equations tended to underestimate the change in clearance over time compared with the change in measured $\mathrm{CL}_{\text {urea }} \beta$-Trace protein is also significantly removed by convection and, hence, not suitable for estimating RKF among patients receiving hemodiafiltration (HDF) [27].

\section{RKF and the Management of Blood Pressure and Body Fluid Levels}

Most hemodialysis patients gain body fluid during the interdialytic period due to very low levels of renal function, and volume control and management have been among the most strenuous tasks for both patients and healthcare providers. Even with the best effort to 
restrict patients' intake of salt and fluid and to maximize the ultrafiltration volume, chronic volume overload may occur, leading to progression of hypertension and cardiovascular disease $[28,29]$. Several studies have shown a relationship between greater interdialytic weight gain or fluid overload and higher cardiovascular mortality risk [30,31], and patients with little or no RKF are likely to accumulate more body fluid [32, 33].

In addition, there seems to be a vicious cycle between decreased RKF and intradialytic hypotension, another risk factor for mortality among hemodialysis patients. Intradialytic hypotension occurs due to multiple factors including impaired cardiac function, autonomic neuropathy, and excessive fluid removal. Intradialytic hypotension may result in decreased renal blood flow, which leads to renal ischemia and, eventually, to further loss of RKF [34, 35]. Decreased RKF, in turn, increases the burden of sodium and water retention, resulting in poorer blood pressure control, higher pulse wave velocities, and the progression of leftventricular hypertrophy [36].

\section{RKF and the Management of Mineral and Bone Disorders}

Mineral and bone disorder (MBD) in ESRD patients is characterized by elevated levels of serum calcium, phosphorus, parathyroid hormone (PTH), and alkaline phosphatase, which eventually lead to an increased risk of cardiovascular disease and mortality by promoting vascular calcification. Several studies have investigated the role of RKF in modifying the progression of MBD. In the cross-sectional study by Chen et al. [37], RKF was a risk factor for vascular calcification independent of other established risk factors, such as age, hemodialysis vintage, diabetes, calcium phosphorus byproducts, and C-reactive protein. RKF is also important in modifying the mortality risk associated with serum phosphorus and intact PTH levels among incident hemodialysis patients [38]. In a large administrative cohort of incident hemodialysis patients in the USA, serum phosphorus and all-cause mortality were positively correlated in general, but the risk associated with hyperphosphatemia was higher among patients with greater RKF. Moreover, the association between all-cause mortality and higher PTH levels was observed only among hemodialysis patients with substantial RKF, but not among those with little or no RKF. Thus, RKF not only facilitates better control of phosphate levels but also affects the entire dynamic between phosphorus levels, intact PTH levels, and mortality rate.

\section{RKF and Nutritional Assessment}

Protein energy wasting and inflammation, or malnutrition-inflammation-cachexia syndrome, is common and associated with mortality among patients with chronic kidney disease including ESRD [39-41]. Albumin, as a surrogate marker of malnutrition, is an independent predictor of quality of life, hospitalization, and mortality risk [42-46]. Interestingly, in a recent cohort study of incident hemodialysis patients, those with greater RKF showed higher serum albumin levels at baseline and maintained these levels during the follow-up period [47]. Additionally, serum albumin levels tend to increase over 12-18 months after dialysis initiation, which is followed by a gradual but continuous decrease. This initial increase in serum albumin level was observed independently of baseline RKF, suggesting that this increase cannot be fully explained by decreased loss of urinary protein with diminished RKF after dialysis initiation. The initial increase in serum albumin can be attributed to an improved appetite following the removal of uremic toxins, improved protein synthesis, and reduced protein degradation due to the resolution of metabolic acidosis. 
The normalized protein catabolic rate (nPCR), a proxy for dietary protein intake among stable hemodialysis patients, has been shown to be associated with the serum albumin level as well as with better survival among hemodialysis patients [42, 48-50]. However, given that the nPCR does not account for urinary urea excretion, protein intake is underestimated with the nPCR among patients with RKF [48]. For example, in a large US cohort of incident hemodialysis patients, the median nPCR with and without accounting for renal urea clearance at baseline was 0.94 and $0.78 \mathrm{~g} / \mathrm{kg}$ per day, respectively. The median within-patient difference in $\mathrm{nPCR}$ was $0.14 \mathrm{~g} / \mathrm{kg}$ per day and was larger among patients with greater RKF. In addition, the association of the nPCR with survival appeared to be stronger when renal $\mathrm{CL}_{\text {urea }}$ was accounted for in the calculation of the nPCR. These findings suggest that renal $\mathrm{CL}_{\text {urea }}$ should be periodically monitored and accounted for when evaluating protein intake using the nPCR among patients with RKF.

\section{RKF and Dialysis Adequacy}

Until now, the results from the National Cooperative Dialysis Study (NCDS), published in 1981, have dictated the current treatment paradigm to achieve a minimal delivered dialysis dose of 1.2 per session in single-pool Kt/V or 2.3 per week in standard Kt/V for thrice-weekly hemodialysis patients with little or no RKF $[51,52]$. Since RKF also contributes to the small solute clearance, the Kidney Disease Outcomes Quality Initiative (KDOQI) guidelines recommend using renal $\mathrm{CL}_{\text {urea }}$ to measure RKF [18]. Renal $\mathrm{CL}_{\text {urea }}$, if present and measured, can be converted into renal standard $\mathrm{Kt} / \mathrm{V}$ so that it can be added to dialysis standard $\mathrm{Kt} / \mathrm{V}$ as follows:

$$
\text { Renal standard } K t / V=\frac{\text { Renal } C L \text { urea }[\mathrm{mL} / \mathrm{min}] \times 10,080[\mathrm{~min}]}{V_{\text {Watson }}[L] \times 1,000} .
$$

A renal $\mathrm{CL}_{\text {urea }}$ value of $3.0 \mathrm{~mL} / \mathrm{min}$ in an average dialysis patient is close to a standard $\mathrm{Kt} / \mathrm{V}$ value of approximately 1.0 per week. Given that the recommended value for standard $\mathrm{Kt} / \mathrm{V}$ is 2.3 , it is suggested that the dialysis frequency may be safely reduced to twice weekly for patients with renal $\mathrm{CL}_{\text {urea }} \geq 3.0 \mathrm{~mL} / \mathrm{min} / 1.73 \mathrm{~m}^{2}$ [18].

One of the major hindrances to the incorporation of RKF into hemodialysis adequacy is the complexity of accounting for the entire function of the remnant kidney. Less frequent hemodialysis treatments may be allowed at lower RKF levels than what is currently suggested given the advantage of RKF over equivalent dialysis urea clearance [53, 54], but the approach to sum up renal and dialysis urea clearance is at least warranted because it assumes the minimum benefit of RKF and because it does not underestimate the potential risk associated with inadequate dialysis. It should be noted that our ability to reduce solute concentrations by intensifying hemodialysis treatment is limited, probably due to the presence of nondialytic solute clearances and/or changes in solute production [55]. Native kidneys provide solute clearance equivalent to or more than that of hemodialysis treatment with the same urea clearance, especially for middle molecules (i.e., $\beta_{2}$-microglobulin) and protein-bound uremic toxins (i.e., indoxyl sulfate and p-cresol sulfate) $[2,56]$. RKF also provides other benefits than solute clearance, such as continuous fluid removal, and more preserved endocrine functions. Indeed, there have been studies suggesting that RKF is more strongly associated with survival among ESRD patients than is dialysis adequacy, even with the same amount of small solute clearance $[57,58]$.

Accordingly, the benefit from hemodialysis treatment may also be attenuated among patients with substantial RKF $[56,58]$. In line with this theoretical concept, Wang et al. [59] reported that the association between higher delivered dialysis dose and better survival was 
linearly attenuated with greater renal $\mathrm{CL}_{\text {urea }}$ among incident hemodialysis patients. Furthermore, the Frequent Hemodialysis Network (FHN) group showed contrasting results in their Daily and Nocturnal trials. The FHN Daily Trial mainly consisted of long-term hemodialysis patients, of whom two-thirds were anuric, and daily in-center frequent hemodialysis resulted in reduced left ventricular mass, better control of blood pressure and serum phosphorus, and better long-term survival [60]. On the other hand, the FHN Nocturnal Trial included patients relatively new to dialysis, half of whom had a urine volume of $0.5 \mathrm{~L}$ or more, and 6-times-weekly home nocturnal hemodialysis resulted in a steeper RKF decline and higher mortality in the frequent hemodialysis group [11,61]. Recent studies have suggested potential advantages of incremental hemodialysis for patients with substantial RKF, such as a slower RKF deterioration rate, greater quality of life, longer longevity of the arteriovenous fistula, and lower medical cost [62-65].

\section{RKF and Survival Prediction}

A prospective observational study first reported that compared with anuric hemodialysis patients, patients with any RKF at the time of dialysis initiation experienced a $56 \%$ lower mortality [9]. The Netherlands Cooperative Study on the Adequacy of Dialysis (NECOSAD-2) investigators also reported that the mortality risk decreased by $56 \%$ with every 1.0 /week increment in renal $\mathrm{Kt} / \mathrm{V}_{\text {urea }}$ at 3 months after the initiation of dialysis. In a prospective cohort study (the CHOICE study), although the baseline urine output was not associated with better survival, the maintained urine output after 1 year (self-reported, 1 cup or $250 \mathrm{~mL} /$ day of urine) was associated with a 30\% reduction in adjusted mortality risk [7]. Maintained RKF was also correlated with a better quality of life, a decreased dose of erythropoiesis-stimulating agents, and reduced inflammation. In order to overcome a potential lead-time bias in these studies, Obi et al. [11] examined the annual change in renal $\mathrm{CL}_{\text {urea }}$ among incident hemodialysis patients and reported a linear association with greater subsequent mortality risk.

\section{How to Protect RKF}

A tailored dialysis therapy for each patient's characteristics potentially preserves RKF when initiating and maintaining hemodialysis therapy. Here, we discuss several possible methods for preserving RKF that can be selected according to a patient's characteristics.

\section{General Care}

Although there are several new strategies that may preserve RKF in hemodialysis patients, it is still important to maintain general principles to protect the residual kidneys, such as avoiding or minimizing nephrotoxic events (i.e., radiocontrast, nonsteroidal antiinflammatory drugs, and aminoglycosides) [66] as well as appropriate control of blood pressure after initiating dialysis. Intradialytic hypotension may accelerate RKF loss via ischemic insults and can be prevented by sodium and water restriction, dialysate cooling, sodium profiling (which is reserved for short-term use), changing the ultrafiltration profile, and acetate-free HDF [67-70]. Using loop diuretics in hemodialysis patients with considerable RKF can also lower interdialytic weight gain and eventually benefit the preservation of RKF [71]. These measures need to be individualized according to patient conditions. Additionally, lower serum calcium levels, higher serum levels of phosphorus, and intact PTH have been associated with a faster decline in RKF $[11,72]$; hence, better control of MBD parameters may result in preserving RKF. 
High-Flux Biocompatible Membrane, Ultrapure Water, and On-Line HDF

Biocompatible dialysis membranes (e.g., polysulfone membrane), when compared to bioincompatible membranes (e.g., cellulose membrane), are associated with the preservation of RKF $[73,74]$. In addition, ultrapure dialysate combined with high-flux synthetic membranes is effective in slowing RKF deterioration with lower C-reactive protein and IL-6 levels, when compared to conventional dialysate [75]. Other studies have also reported similar RKF declines between patients on peritoneal dialysis and those treated with hemodialysis utilizing high-flux biocompatible membranes and ultrapure dialysate $[16,76]$. On-line HDF, a wellknown method that has a greater clearance of $\beta_{2}$-microglobulin than conventional hemodialysis by its convection [77], uses ultrapure dialysate because it requires the dialysate to be directly infused into the extracorporeal circuit. Several studies have shown that RKF or urine volume was more preserved among patients treated with on-line HDF than among those treated with conventional hemodialysis $[78,79]$. These observations may be attributed to fewer intradialytic hypotensive episodes and reduced dialyzer-induced systemic inflammation [80].

\section{Incremental Hemodialysis}

The core concept of incremental dialysis is the smooth "transition," rather than abrupt "start," from conservative management of chronic kidney disease to dialysis therapy [81]. This approach has been successfully used for peritoneal dialysis patients, not for hemodialysis patients. Additionally, patients on incremental peritoneal dialysis showed a lower decline in RKF, a similar survival rate, and fewer hospitalizations than standard peritoneal dialysis patients [82]. With incremental hemodialysis, dialysis treatment is initiated once or twice weekly - rather than thrice weekly, as in the conventional regimen - if patients have substantial RKF. Then, the hemodialysis frequency is gradually increased in accordance with RKF deterioration. Kalantar-Zadeh and Casino [83] and Kalantar-Zadeh et al. [84] suggested an 11-criteria matrix for successfully implementing twice-weekly hemodialysis in clinical practice, including urine volume and interdialytic fluid gain.

In addition to a better quality of life, lower medical cost, and longer patency of vascular access, several studies have demonstrated that compared to ESRD patients who started hemodialysis therapy at the conventional thrice-weekly frequency, patients managed with incremental hemodialysis showed a slower decline in RKF (Table 2).

Compared to patients on thrice-weekly hemodialysis, twice-weekly hemodialysis patients were shown to have more urine output and reduced hospitalization rates [62]. Also, the rate of RKF decline among patients with twice-weekly hemodialysis was similar to that among patients with peritoneal dialysis [85]. In a retrospective cohort of patients under a hemodialysis regimen in Shanghai, the prevalence of RKF loss was lower among patients treated with twice-weekly hemodialysis than among those treated with thrice-weekly hemodialysis, especially during the first year of dialysis [34]. Additionally, in a longitudinal cohort study of incident hemodialysis patients, those treated with an incremental regimen showed a slower decline in $\mathrm{CL}_{\text {urea }}$ during the first year of dialysis and similar survival thereafter when compared to those with conventional hemodialysis thereafter [64]. However, among patients with $\mathrm{CL}_{\text {urea }}<3.0 \mathrm{~mL} / \mathrm{min} / 1.73 \mathrm{~m}^{2}$, incremental hemodialysis was associated with an increased mortality risk. Therefore, while incremental hemodialysis may preserve RKF after dialysis initiation, RKF appears to be an important factor that predicts which patients would benefit from an incremental hemodialysis regimen.

\section{Low-Protein Diet}

A low-protein diet results in a reduced burden of nitrogen, phosphate, and potassium, and is an effective strategy for postponing dialysis initiation for patients with chronic kidney 
Table 2. Initial and follow-up RKF in hemodialysis patients

\begin{tabular}{|c|c|c|c|c|c|c|}
\hline $\begin{array}{l}\text { Study [Ref.] } \\
\text { (study design) }\end{array}$ & Year & $\begin{array}{l}\text { RKF index } \\
\text { (unit) }\end{array}$ & Groups of interest & $\begin{array}{l}\text { Subjects, } \\
n\end{array}$ & $\begin{array}{l}\text { Baseline } \\
\text { RKF }\end{array}$ & $\begin{array}{l}\text { Follow-up RKF or } \\
\text { decline rate }\end{array}$ \\
\hline $\begin{array}{l}\text { Vilar et al. [10] } \\
\text { (observational) }\end{array}$ & 2009 & $\begin{array}{l}\mathrm{CL}_{\text {urea }} \\
\left(\mathrm{mL} / \mathrm{min} / 1.73 \mathrm{~m}^{2}\right)\end{array}$ & Incremental high-flux HD & 650 & $3.1 \pm 1.9$ at $3 \mathrm{M}$ & $0.9 \pm 1.2$ at $60 \mathrm{M}$ \\
\hline $\begin{array}{l}\text { Lin et al. [62] } \\
\text { (observational) }\end{array}$ & 2009 & $\begin{array}{l}\mathrm{CL}_{\mathrm{cr}} \\
(\mathrm{mL} / \mathrm{min})\end{array}$ & $\begin{array}{l}\text { 2/w HD } \\
3 / w \text { HD }\end{array}$ & $\begin{array}{l}23 \\
51\end{array}$ & $\begin{array}{l}3.4 \pm 1.4 \\
4.1 \pm 2.0\end{array}$ & $\begin{array}{l}0.06 / \mathrm{M} \\
0.36 / \mathrm{M} \\
\text { (decline rate) }\end{array}$ \\
\hline $\begin{array}{l}\text { Teruel-Briones } \\
\text { et al. [85] } \\
\text { (observational) }\end{array}$ & 2013 & $\begin{array}{l}\mathrm{rGFR} \\
\left(\mathrm{mL} / \mathrm{min} / 1.73 \mathrm{~m}^{2}\right)\end{array}$ & $\begin{array}{l}\text { 2/w HD } \\
\text { 3/w HD } \\
\text { PD }\end{array}$ & $\begin{array}{l}61 \\
49 \\
83\end{array}$ & $\begin{array}{l}6.1 \pm 2.1 \\
5.4 \pm 2.9 \\
7.0 \pm 3.2\end{array}$ & $\begin{array}{l}0.18 / \mathrm{M} \\
0.33 / \mathrm{M} \\
0.18 / \mathrm{M} \\
\text { (decline rate) }\end{array}$ \\
\hline $\begin{array}{l}\text { Caria et al. [91] } \\
\text { (observational) }\end{array}$ & 2014 & $\begin{array}{l}\mathrm{rGFR} \\
\left(\mathrm{mL} / \mathrm{min} / 1.73 \mathrm{~m}^{2}\right)\end{array}$ & $\begin{array}{l}\text { 1/w HD combined with } \\
\text { low-protein diet (CDDP) } \\
\text { 3/w HD }\end{array}$ & $\begin{array}{l}38 \\
30\end{array}$ & $\begin{array}{l}7.8 \pm 1.9 \\
9.2 \pm 4.2\end{array}$ & $\begin{array}{l}0.13 / \mathrm{M} \\
1.53 / \mathrm{M} \\
\text { (decline rate) }\end{array}$ \\
\hline $\begin{array}{l}\text { Zhang et al. [34] } \\
\text { (observational) }\end{array}$ & 2014 & $\begin{array}{l}\mathrm{rGFR} \\
\left(\mathrm{mL} / \mathrm{min} / 1.73 \mathrm{~m}^{2}\right)\end{array}$ & $\begin{array}{l}\text { 2/w HD } \\
3 / w \text { HD }\end{array}$ & $\begin{array}{l}30 \\
55\end{array}$ & & $\begin{array}{l}34 \pm 32 \mathrm{M} \\
21 \pm 19 \mathrm{M} \\
\text { (time to RKF loss) }\end{array}$ \\
\hline $\begin{array}{l}\text { Obi et al. [64] } \\
\text { (observational) }\end{array}$ & 2016 & $\begin{array}{l}\mathrm{CL}_{\text {urea }} \\
\left(\mathrm{mL} / \mathrm{min} / 1.73 \mathrm{~m}^{2}\right)\end{array}$ & $\begin{array}{l}\text { Incremental HD } \\
\text { Matched patients on } \\
\text { conventional HD }\end{array}$ & $\begin{array}{r}351 \\
8,068\end{array}$ & $\begin{array}{l}4.8 \\
4.6\end{array}$ & $\begin{array}{l}\mathrm{CL}_{\text {urea }} \text { was more } \\
\text { preserved by } 16 \% \text { in } \\
\text { incremental vs. } \\
\text { conventional HD }\end{array}$ \\
\hline $\begin{array}{l}\text { Nakao et al. [92] } \\
\text { (observational) }\end{array}$ & 2018 & $\begin{array}{l}\mathrm{rGFR} \\
(\mathrm{mL} / \mathrm{min})\end{array}$ & $\begin{array}{l}\text { 1/w HD + low-protein } \\
\text { low-salt diet } \\
\text { 3/w HD }\end{array}$ & $\begin{array}{l}112 \\
30\end{array}$ & $\begin{array}{l}3.0 \pm 0.7 \\
\mathrm{~N} / \mathrm{A}\end{array}$ & $\begin{array}{l}2.1 \pm 0.6 \text { at } 12 \mathrm{M} \\
0.7 \pm 0.5 \text { at } 12 \mathrm{M}\end{array}$ \\
\hline $\begin{array}{l}\text { Hartmann et al. } \\
\text { [74] (RCT) }\end{array}$ & 1997 & $\begin{array}{l}\mathrm{CL}_{\mathrm{cr}} \\
(\mathrm{mL} / \mathrm{min})\end{array}$ & $\begin{array}{l}\text { 3/w HD with polysulfone } \\
\text { membrane } \\
\text { 3/w HD with cellulose acetate } \\
\text { membrane }\end{array}$ & $\begin{array}{l}10 \\
10\end{array}$ & & $\begin{array}{l}0.37 \pm 0.06 / \mathrm{M} \\
0.50 \pm 0.04 / \mathrm{M} \\
\text { (decline rate) }\end{array}$ \\
\hline $\begin{array}{l}\text { Jansen et al. [67] } \\
\text { (observational) }\end{array}$ & 2002 & $\begin{array}{l}\mathrm{rGFR} \\
\left(\mathrm{mL} / \mathrm{min} / 1.73 \mathrm{~m}^{2}\right)\end{array}$ & $\begin{array}{l}\text { 3/w HD } \\
\text { PD }\end{array}$ & $\begin{array}{l}279 \\
243\end{array}$ & $\begin{array}{l}5.9 \pm 2.8 \\
6.4 \pm 2.4\end{array}$ & $\begin{array}{l}\text { Relative decline in } \\
\text { rGFR was faster by } \\
20 \% \text { in HD vs. PD at } \\
6 \mathrm{M}\end{array}$ \\
\hline $\begin{array}{l}\text { Lang et al. [14] } \\
\text { (observational) }\end{array}$ & 2001 & $\begin{array}{l}\mathrm{CL}_{\mathrm{cr}} \\
(\mathrm{mL} / \mathrm{min})\end{array}$ & $\begin{array}{l}\text { 3/w HD with biocompatible } \\
\text { membrane } \\
\text { 3/w HD with bioincompatible } \\
\text { membrane } \\
\text { CAPD }\end{array}$ & $\begin{array}{l}15 \\
15 \\
15\end{array}$ & $\begin{array}{l}7.6 \pm 1.6 \\
7.4 \pm 1.8 \\
7.4 \pm 1.2\end{array}$ & $\begin{array}{l}1.9 \\
3.6 \\
0.6 \\
\left(\text { decrease in } \mathrm{CL}_{\mathrm{cr}}\right. \\
\text { by } 6 \mathrm{M})\end{array}$ \\
\hline $\begin{array}{l}\text { McKane et al. [16] } \\
\text { (observational) }\end{array}$ & 2002 & $\begin{array}{l}\mathrm{CL}_{\text {urea }} \\
\left(\mathrm{mL} / \mathrm{min} / 1.73 \mathrm{~m}^{2}\right)\end{array}$ & $\begin{array}{l}\text { 3/w HD with high-flux } \\
\text { biocompatible membrane } \\
\text { and ultrapure water } \\
\text { CAPD }\end{array}$ & 300 & 4.2 & $\begin{array}{l}2.1 \\
\left(\mathrm{CL}_{\text {urea }} \text { at } 18 \mathrm{M}\right)\end{array}$ \\
\hline $\begin{array}{l}\text { Schiffl et al. [75] } \\
\text { (RCT) }\end{array}$ & 2002 & $\begin{array}{l}\mathrm{CL}_{\mathrm{cr}} \\
(\mathrm{mL} / \mathrm{min})\end{array}$ & $\begin{array}{l}\text { Ultrapure dialysate } \\
\text { Conventional dialysate }\end{array}$ & $\begin{array}{l}15 \\
15\end{array}$ & $\begin{array}{l}7.9 \pm 2.0 \\
7.9 \pm 1.8\end{array}$ & $\begin{array}{l}4.3 \pm 1.8 \text { at } 24 \mathrm{M} \\
2.5 \pm 1.8 \text { at } 24 \mathrm{M}\end{array}$ \\
\hline
\end{tabular}

CAPD, continuous ambulatory peritoneal dialysis; CDDP, Combined Diet Dialysis Program; $\mathrm{CL}_{\text {urea, }}$ residual renal urea clearance; GFR, glomerular filtration rate; rGFR, residual GFR estimated as the arithmetic mean of creatinine and urea clearance; $\mathrm{CL}_{\mathrm{cr}}$, $\mathrm{creatinine}$ clearance; HD, hemodialysis; M, months; PD, peritoneal dialysis; RCT, randomized clinical trial; RKF, residual kidney function. 
disease not on dialysis $[86,87]$. Inadequate protein intake may lead to protein wasting, one of the major concerns among dialysis patients, but small retrospective studies of predialysis patients have suggested that even a very-low-protein diet $(0.3 \mathrm{~g} / \mathrm{kg}$ body weight [BW]/day) supplemented with keto/amino acids may not compromise long-term patient safety [88, 89]. In this context, a low-protein diet has been integrated with a less frequent hemodialysis program at the initiation of dialysis, showing significant advantages in RKF protection. Although a low-protein diet has compliance issues and safety concerns for patients on dialysis [90], Caria et al. [91] showed that motivated patients with incident ESRD were closely adherent to the "Combined Diet Dialysis Program," which included a low-protein diet $(0.6 \mathrm{~g} /$ $\mathrm{kg}$ BW/day) combined with once-weekly hemodialysis. Furthermore, the patients enrolled in this program experienced slower declines in RKF, better control of anemia and mineral disorders, and lower hospitalization rates while maintaining a good nutritional status when compared to those who initiated conventional thrice-weekly hemodialysis. Consistent findings were observed in a prospective cohort from Japan [92].

On the other hand, several observational studies have shown that lower serum albumin levels are associated with a steeper RKF decline and higher mortality [11, 46, 48, 93]. Along with the fact that the hemodialysis procedure per se increases net protein catabolism, a lowprotein diet may be discouraged because of concerns regarding protein energy wasting [94, 95]. Indeed, many dialysis patients have a protein intake lower than the recommended dietary allowance level $(0.8 \mathrm{~g} / \mathrm{kg} \mathrm{BW} /$ day $)$, and a recent randomized clinical trial revealed that highprotein meals during dialysis increase serum albumin levels [50].

However, there are distinct differences between unintentional low protein intake and an intentional low-protein diet. Unintentional low protein intake, as measured in most observational studies, is usually due to appetite loss and/or dysphagia and is strongly associated with the patient's disease condition. It is also accompanied by generalized insufficiency or deficiency of nutrients such as energy and vitamins. In contrast, an intentional low-protein diet, which is a dietary intervention, requires patients to consume high-energy foods, which effectively suppress protein catabolism related to low protein intake [96]. Keto/amino acids and deficient vitamins are also supplemented if indicated. Therefore, a low-protein diet may not necessarily increase the risk of morbidity and mortality even among hemodialysis patients if it allows patients to spend fewer days with restrictions for dialysis treatment.

Nevertheless, it has been practically challenging to adhere to such dietary interventions with low protein and high energy intake [97]. Given the potential risk of protein wasting induced by inadequate energy intake, the implementation of a low-protein diet may be restricted to highly motivated and well-prepared patients, as was done in those studies showing the safety of protein restriction $[88,89]$. Therefore, it is yet to be determined whether a dietary intervention including a low-protein diet has beneficial effects by protecting RKF in ESRD.

\section{Future Directions}

We propose several strategies for a broad implementation of RKF-based individualized hemodialysis regimens. First, the development of concise and reliable methods for estimating RKF levels is essential, because one of the key barriers is the labor-intensive urine collection. Several methods have been developed for estimating RKF without urine collection, but it remains unclear whether the discrepancies between estimated and actual levels are acceptable for clinical decision-making with regard to such an individualized therapy. Second, simple guides are also necessary in order to identify candidates for individualized therapy and to modify hemodialysis treatment (especially in terms of treatment time and frequency) 
Hur et al.: Residual Kidney Function and Hemodialysis

according to RKF levels. Urea kinetic modelling is required to obtain precise total $\mathrm{CL}_{\text {urea }}$ by combining dialysis and residual renal clearance, but the currently available software is not easy enough to use in daily clinical practice. Third, such efforts to individualize hemodialysis treatment should be appropriately acknowledged in the reimbursement system. We believe that these measures, if taken appropriately, would ensure precision medicine and patientcenteredness in nephrology practice.

\section{Disclosure Statement}

K.K.-Z. is supported by National Institute of Diabetes and Digestive and Kidney Diseases (NIDDK) grants K24-DK091419 and U01-DK102163, and philanthropic grants from Harold Simmons, Louis Chang, and Dr. Joseph Lee, outside the submitted work. K.K.-Z. has also received honoraria and/or support from Abbott, AbbVie, Alexion, Amgen, the American Society of Nephrology, AstraZeneca, Aveo, Chugai, DaVita, Fresenius, Genentech, Haymarket Media, Hospira, Kabi, Keryx, Relypsa, Resverlogix, Sanofi, Shire, Vifor, and ZS Pharma, outside the submitted work. Y.O. has received honoraria and/or support from Chugai and Ono, outside the submitted work. K.K.-Z. was the medical director of DaVita Harbor-UCLA/MFI in Long Beach, CA, USA, during 2007-2012. The other authors have not declared any conflict of interest.

\section{References}

1 Mathew AT, Fishbane S, Obi Y, Kalantar-Zadeh K. Preservation of residual kidney function in hemodialysis patients: reviving an old concept. Kidney Int. 2016 Aug;90(2):262-71.

2 Leong SC, Sao JN, Taussig A, Plummer NS, Meyer TW, Sirich TL. Residual Function Effectively Controls Plasma Concentrations of Secreted Solutes in Patients on Twice Weekly Hemodialysis. J Am Soc Nephrol. 2018 Jul; 29(7):1992-9.

3 Maeda K, Shinzato T, Ota T, Kobayakawa H, Takai I, Fujita Y, et al. Beta-2-microglobulin generation rate and clearance rate in maintenance hemodialysis patients. Nephron. 1990;56(2):118-25.

4 Brown PH, Kalra PA, Turney JH, Cooper EH. Serum low-molecular-weight proteins in haemodialysis patients: effect of residual renal function. Nephrol Dial Transplant. 1988;3(2):169-73.

5 Grantham JJ, Wallace DP. Return of the secretory kidney. Am J Physiol Renal Physiol. 2002 Jan;282(1):F1-9.

6 Lowenstein J, Grantham JJ. The rebirth of interest in renal tubular function. Am J Physiol Renal Physiol. 2016 Jun;310(11):F1351-5.

7 Shafi T, Jaar BG, Plantinga LC, Fink NE, Sadler JH, Parekh RS, et al. Association of residual urine output with mortality, quality of life, and inflammation in incident hemodialysis patients: the Choices for Healthy Outcomes in Caring for End-Stage Renal Disease (CHOICE) Study. Am J Kidney Dis. 2010 Aug;56(2):348-58.

8 Suda T, Hiroshige K, Ohta T, Watanabe Y, Iwamoto M, Kanegae K, et al. The contribution of residual renal function to overall nutritional status in chronic haemodialysis patients. Nephrol Dial Transplant. 2000 Mar; 15(3):396-401.

9 Shemin D, Bostom AG, Laliberty P, Dworkin LD. Residual renal function and mortality risk in hemodialysis patients. Am J Kidney Dis. 2001 Jul;38(1):85-90.

10 Vilar E, Wellsted D, Chandna SM, Greenwood RN, Farrington K. Residual renal function improves outcome in incremental haemodialysis despite reduced dialysis dose. Nephrol Dial Transplant. 2009 Aug;24(8):2502-10.

11 Obi Y, Rhee CM, Mathew AT, Shah G, Streja E, Brunelli SM, et al. Residual Kidney Function Decline and Mortality in Incident Hemodialysis Patients. J Am Soc Nephrol. 2016 Dec;27(12):3758-68.

12 Rottembourg J, Issad B, Gallego JL, Degoulet P, Aime F, Gueffaf B, et al. Evolution of residual renal function in patients undergoing maintenance haemodialysis or continuous ambulatory peritoneal dialysis. Proc Eur Dial Transplant Assoc. 1983;19:397-403.

13 Misra M, Vonesh E, Van Stone JC, Moore HL, Prowant B, Nolph KD. Effect of cause and time of dropout on the residual GFR: a comparative analysis of the decline of GFR on dialysis. Kidney Int. 2001 Feb;59(2):754-63.

14 Lang SM, Bergner A, Töpfer M, Schiffl H. Preservation of residual renal function in dialysis patients: effects of dialysis-technique-related factors. Perit Dial Int. 2001 Jan-Feb;21(1):52-7.

15 Eknoyan G, Beck GJ, Cheung AK, Daugirdas JT, Greene T, Kusek JW, et al.; Hemodialysis (HEMO) Study Group. Effect of dialysis dose and membrane flux in maintenance hemodialysis. N Engl J Med. 2002 Dec;347(25): 2010-9.

16 McKane W, Chandna SM, Tattersall JE, Greenwood RN, Farrington K. Identical decline of residual renal function in high-flux biocompatible hemodialysis and CAPD. Kidney Int. 2002 Jan;61(1):256-65. 
Hur et al.: Residual Kidney Function and Hemodialysis

Jindal $\mathrm{KK}$, Goldstein $\mathrm{MB}$. Urea kinetic modeling in ch

\section{solutions. Semin Dial. 1988;1(2):82-5.}

20 Daugirdas JT, Blake PG, Ing TS. Handbook of dialysis. Philadelphia (PA): Lippincott Williams \& Wilkins; 2014.

21 Obi Y, Kalantar-Zadeh K, Streja E, Daugirdas JT. Prediction equation for calculating residual kidney urea clearance using urine collections for different hemodialysis treatment frequencies and interdialytic intervals. Nephrol Dial Transplant. 2018 Mar;33(3):530-539.

22 Casino FG, Lopez T. The equivalent renal urea clearance: a new parameter to assess dialysis dose. Nephrol Dial Transplant. 1996 Aug;11(8):1574-81.

23 Tattersall J, Martin-Malo A, Pedrini L, Basci A, Canaud B, Fouque D, et al. EBPG guideline on dialysis strategies. Nephrol Dial Transplant. 2007 May;22 Suppl 2:ii5-21.

24 Revillard JP, Vincent C. Structure and metabolism of beta-2-microglobulin. Contrib Nephrol. 1988;62:44-53.

25 Shafi T, Michels WM, Levey AS, Inker LA, Dekker FW, Krediet RT, et al. Estimating residual kidney function in dialysis patients without urine collection. Kidney Int. 2016 May;89(5):1099-110.

26 Wong J, Sridharan S, Berdeprado J, Vilar E, Viljoen A, Wellsted D, et al. Predicting residual kidney function in hemodialysis patients using serum $\beta$-trace protein and $\beta 2$-microglobulin. Kidney Int. 2016 May;89(5):1090-8.

27 Gerhardt T, Pöge U, Stoffel-Wagner B, Klein B, Klehr HU, Sauerbruch T, et al. Serum levels of beta-trace protein and its association to diuresis in haemodialysis patients. Nephrol Dial Transplant. 2008 Jan;23(1):309-14.

28 Agarwal R. What are the Consequences of Volume Expansion in Chronic Dialysis Patients?: Hypertension as a Manifestation of Volume Overload in Hemodialysis Patients. Semin Dial. 2015 May-Jun;28(3):231-2.

29 Agarwal R. Epidemiology of interdialytic ambulatory hypertension and the role of volume excess. Am J Nephrol. 2011;34(4):381-90.

30 Flythe JE, Kimmel SE, Brunelli SM. Rapid fluid removal during dialysis is associated with cardiovascular morbidity and mortality. Kidney Int. 2011 Jan;79(2):250-7.

31 Chou JA, Streja E, Nguyen DV, Rhee CM, Obi Y, Inrig JK, et al. Intradialytic hypotension, blood pressure changes and mortality risk in incident hemodialysis patients. Nephrol Dial Transplant. 2018 Jan;33(1):149-59.

32 Kalantar-Zadeh K, Regidor DL, Kovesdy CP, Van Wyck D, Bunnapradist S, Horwich TB, et al. Fluid retention is associated with cardiovascular mortality in patients undergoing long-term hemodialysis. Circulation. 2009 Feb;119(5):671-9.

33 Zoccali C, Moissl U, Chazot C, Mallamaci F, Tripepi G, Arkossy O, et al. Chronic Fluid Overload and Mortality in ESRD. J Am Soc Nephrol. 2017 Aug;28(8):2491-7.

34 Zhang M, Wang M, Li H, Yu P, Yuan L, Hao C, et al. Association of initial twice-weekly hemodialysis treatment with preservation of residual kidney function in ESRD patients. Am J Nephrol. 2014;40(2):140-50.

35 Daugirdas JT. Dialysis hypotension: a hemodynamic analysis. Kidney Int. 1991 Feb;39(2):233-46.

36 Wang AY, Wang M, Woo J, Law MC, Chow KM, Li PK, et al. A novel association between residual renal function and left ventricular hypertrophy in peritoneal dialysis patients. Kidney Int. 2002 Aug;62(2):639-47.

37 Chen HC, Chou CY, Jheng JS, Chen IR, Liang CC, Wang SM, et al. Loss of Residual Renal Function is Associated With Vascular Calcification in Hemodialysis Patients. Ther Apher Dial. 2016 Feb;20(1):27-30.

38 Wang M, Obi Y, Streja E, Rhee CM, Lau WL, Chen J, et al. Association of Parameters of Mineral Bone Disorder with Mortality in Patients on Hemodialysis according to Level of Residual Kidney Function. Clin J Am Soc Nephrol. 2017 Jul;12(7):1118-27.

39 Kalantar-Zadeh K, Kopple JD, Block G, Humphreys MH. A malnutrition-inflammation score is correlated with morbidity and mortality in maintenance hemodialysis patients. Am J Kidney Dis. 2001 Dec;38(6):1251-63.

40 Lowrie EG. Acute-phase inflammatory process contributes to malnutrition, anemia, and possibly other abnormalities in dialysis patients. Am J Kidney Dis. 1998 Dec;32(6 Suppl 4):S105-12.

41 Obi Y, Qader H, Kovesdy CP, Kalantar-Zadeh K. Latest consensus and update on protein-energy wasting in chronic kidney disease. Curr Opin Clin Nutr Metab Care. 2015 May;18(3):254-62.

42 Kalantar-Zadeh K, Kilpatrick RD, Kuwae N, McAllister CJ, Alcorn H Jr, Kopple JD, et al. Revisiting mortality predictability of serum albumin in the dialysis population: time dependency, longitudinal changes and population-attributable fraction. Nephrol Dial Transplant. 2005 Sep;20(9):1880-8.

43 de Roij van Zuijdewijn CL, ter Wee PM, Chapdelaine I, Bots ML, Blankestijn PJ, van den Dorpel MA, et al. A Comparison of 8 Nutrition-Related Tests to Predict Mortality in Hemodialysis Patients. J Ren Nutr. 2015 Sep; 25(5):412-9.

44 Bergström J. Nutrition and mortality in hemodialysis. J Am Soc Nephrol. 1995 Nov;6(5):1329-41.

45 Iseki K, Kawazoe N, Fukiyama K. Serum albumin is a strong predictor of death in chronic dialysis patients. Kidney Int. 1993 Jul;44(1):115-9.

46 Owen WF Jr, Lew NL, Liu Y, Lowrie EG, Lazarus JM. The urea reduction ratio and serum albumin concentration as predictors of mortality in patients undergoing hemodialysis. N Engl J Med. 1993 Sep;329(14):1001-6.

47 Eriguchi R, Obi Y, Rhee CM, Chou JA, Tortorici AR, Mathew AT, et al. Changes in urine volume and serum albumin in incident hemodialysis patients. Hemodial Int. 2017 Oct;21(4):507-18. 
Hur et al.: Residual Kidney Function and Hemodialysis

48 Eriguchi R, Obi Y, Streja E, Tortorici AR, Rhee CM, Soohoo M, et al. Longitudinal Associations among Renal Urea Clearance-Corrected Normalized Protein Catabolic Rate, Serum Albumin, and Mortality in Patients on Hemodialysis. Clin J Am Soc Nephrol. 2017 Jul;12(7):1109-17.

49 Shinaberger CS, Kilpatrick RD, Regidor DL, McAllister CJ, Greenland S, Kopple JD, et al. Longitudinal associations between dietary protein intake and survival in hemodialysis patients. Am J Kidney Dis. 2006 Jul;48(1): 37-49.

50 Rhee CM, You AS, Koontz Parsons T, Tortorici AR, Bross R, St-Jules DE, et al. Effect of high-protein meals during hemodialysis combined with lanthanum carbonate in hypoalbuminemic dialysis patients: findings from the FrEDI randomized controlled trial. Nephrol Dial Transplant. 2017 Jul;32(7):1233-43.

51 Lowrie EG, Laird NM, Parker TF, Sargent JA. Effect of the hemodialysis prescription of patient morbidity: report from the National Cooperative Dialysis Study. N Engl J Med. 1981 Nov;305(20):1176-81.

52 Gotch FA, Sargent JA. A mechanistic analysis of the National Cooperative Dialysis Study (NCDS). Kidney Int. 1985 Sep;28(3):526-34.

53 Basile C, Casino FG, Kalantar-Zadeh K. Is incremental hemodialysis ready to return on the scene? From empiricism to kinetic modelling. J Nephrol. 2017 Aug;30(4):521-9.

54 Casino FG, Basile C. The variable target model: a paradigm shift in the incremental haemodialysis prescription. Nephrol Dial Transplant. 2017 Jan;32(1):182-90.

55 Sirich TL, Fong K, Larive B, Beck GJ, Chertow GM, Levin NW, et al.; Frequent Hemodialysis Network (FHN) Trial Group. Limited reduction in uremic solute concentrations with increased dialysis frequency and time in the Frequent Hemodialysis Network Daily Trial. Kidney Int. 2017 May; 91(5):1186-92.

56 Roumelioti ME, Nolin T, Unruh ML, Argyropoulos C. Revisiting the Middle Molecule Hypothesis of Uremic Toxicity: A Systematic Review of Beta 2 Microglobulin Population Kinetics and Large Scale Modeling of Hemodialysis Trials In Silico. PLoS One. 2016 Apr;11(4):e0153157.

57 Bargman JM, Thorpe KE, Churchill DN; CANUSA Peritoneal Dialysis Study Group. Relative contribution of residual renal function and peritoneal clearance to adequacy of dialysis: a reanalysis of the CANUSA study. J Am Soc Nephrol. 2001 Oct;12(10):2158-62.

58 Termorshuizen F, Dekker FW, van Manen JG, Korevaar JC, Boeschoten EW, Krediet RT; NECOSAD Study Group. Relative contribution of residual renal function and different measures of adequacy to survival in hemodialysis patients: an analysis of the Netherlands Cooperative Study on the Adequacy of Dialysis (NECOSAD)-2. J Am Soc Nephrol. 2004 Apr;15(4):1061-70.

59 Wang M, Obi Y, Streja E, Rhee CM, Chen J, Hao C, et al. Impact of residual kidney function on hemodialysis adequacy and patient survival. Nephrol Dial Transplant. 2018 Oct;33(10):1823-31.

60 Chertow GM, Levin NW, Beck GJ, Daugirdas JT, Eggers PW, Kliger AS, et al.; Frequent Hemodialysis Network (FHN) Trials Group. Long-Term Effects of Frequent In-Center Hemodialysis. J Am Soc Nephrol. 2016 Jun; 27(6):1830-6.

61 Daugirdas JT, Leypoldt JK, Akonur A, Greene T, Depner TA; FHN Trial Group. Improved equation for estimating single-pool Kt/V at higher dialysis frequencies. Nephrol Dial Transplant. 2013 Aug;28(8):2156-60.

62 Lin YF, Huang JW, Wu MS, Chu TS, Lin SL, Chen YM, et al. Comparison of residual renal function in patients undergoing twice-weekly versus three-times-weekly haemodialysis. Nephrology (Carlton). 2009 Feb;14(1): 59-64.

63 Hanson JA, Hulbert-Shearon TE, Ojo AO, Port FK, Wolfe RA, Agodoa LY, et al. Prescription of twice-weekly hemodialysis in the USA. Am J Nephrol. 1999;19(6):625-33.

64 Obi Y, Streja E, Rhee CM, Ravel V, Amin AN, Cupisti A, et al. Incremental Hemodialysis, Residual Kidney Function, and Mortality Risk in Incident Dialysis Patients: A Cohort Study. Am J Kidney Dis. 2016 Aug;68(2): 256-65.

65 Cooper BA, Branley P, Bulfone L, Collins JF, Craig JC, Fraenkel MB, et al.; IDEAL Study. A randomized, controlled trial of early versus late initiation of dialysis. N Engl J Med. 2010 Aug;363(7):609-19.

66 Janousek R, Krajina A, Peregrin JH, Dusilova-Sulkova S, Renc O, Hajek J, et al. Effect of intravascular iodinated contrast media on natural course of end-stage renal disease progression in hemodialysis patients: a prospective study. Cardiovasc Intervent Radiol. 2010 Feb;33(1):61-6.

67 Jansen MA, Hart AA, Korevaar JC, Dekker FW, Boeschoten EW, Krediet RT; NECOSAD Study Group. Predictors of the rate of decline of residual renal function in incident dialysis patients. Kidney Int. 2002 Sep;62(3):104653.

68 Mustafa RA, Bdair F, Akl EA, Garg AX, Thiessen-Philbrook H, Salameh H, et al. Effect of Lowering the Dialysate Temperature in Chronic Hemodialysis: A Systematic Review and Meta-Analysis. Clin J Am Soc Nephrol. 2016 Mar;11(3):442-57.

69 Zhou YL, Liu HL, Duan XF, Yao Y, Sun Y, Liu Q. Impact of sodium and ultrafiltration profiling on haemodialysisrelated hypotension. Nephrol Dial Transplant. 2006 Nov;21(11):3231-7.

70 Dunne N. A meta-analysis of sodium profiling techniques and the impact on intradialytic hypotension. Hemodial Int. 2017 Jul;21(3):312-22.

71 Bragg-Gresham JL, Fissell RB, Mason NA, Bailie GR, Gillespie BW, Wizemann V, et al. Diuretic use, residual renal function, and mortality among hemodialysis patients in the Dialysis Outcomes and Practice Pattern Study (DOPPS). Am J Kidney Dis. 2007 Mar;49(3):426-31.

72 Moist LM, Port FK, Orzol SM, Young EW, Ostbye T, Wolfe RA, et al. Predictors of loss of residual renal function among new dialysis patients. J Am Soc Nephrol. 2000 Mar;11(3):556-64. 
Hur et al.: Residual Kidney Function and Hemodialysis

73 Van Stone JC. The effect of dialyzer membrane and etiology of kidney disease on the preservation of residual renal function in chronic hemodialysis patients. ASAIO J. 1995 Jul-Sep;41(3):M713-6.

74 Hartmann J, Fricke H, Schiffl H. Biocompatible membranes preserve residual renal function in patients undergoing regular hemodialysis. Am J Kidney Dis. 1997 Sep;30(3):366-73.

75 Schiffl H, Lang SM, Fischer R. Ultrapure dialysis fluid slows loss of residual renal function in new dialysis patients. Nephrol Dial Transplant. 2002 Oct;17(10):1814-8.

76 de Jager DJ, Halbesma N, Krediet RT, Boeschoten EW, le Cessie S, Dekker FW, et al.; NECOSAD Study Group. Is the decline of renal function different before and after the start of dialysis? Nephrol Dial Transplant. 2013 Mar; 28(3):698-705.

77 Ward RA, Schmidt B, Hullin J, Hillebrand GF, Samtleben W. A comparison of on-line hemodiafiltration and high-flux hemodialysis: a prospective clinical study. J Am Soc Nephrol. 2000 Dec;11(12):2344-50.

78 Hyodo T, Koutoku N. Preservation of residual renal function with HDF. Contrib Nephrol. 2011;168:204-12.

79 Schiffl H, Lang SM, Fischer R. Effects of high efficiency post-dilution on-line hemodiafiltration or conventional hemodialysis on residual renal function and left ventricular hypertrophy. Int Urol Nephrol. 2013 Oct;45(5): 1389-96.

80 Vaslaki LR, Berta K, Major L, Weber V, Weber C, Wojke R, et al. On-line hemodiafiltration does not induce inflammatory response in end-stage renal disease patients: results from a multicenter cross-over study. Artif Organs. 2005 May;29(5):406-12.

81 Golper TA. Incremental Hemodialysis: How I Do It. Semin Dial. 2016 Nov; 29(6):476-80.

82 Sandrini M, Vizzardi V, Valerio F, Ravera S, Manili L, Zubani R, et al. Incremental peritoneal dialysis: a 10 year single-centre experience. J Nephrol. 2016 Dec;29(6):871-9.

83 Kalantar-Zadeh K, Casino FG. Let us give twice-weekly hemodialysis a chance: revisiting the taboo. Nephrol Dial Transplant. 2014 Sep;29(9):1618-20.

84 Kalantar-Zadeh K, Crowley ST, Beddhu S, Chen JL, Daugirdas JT, Goldfarb DS, et al. Renal Replacement Therapy and Incremental Hemodialysis for Veterans with Advanced Chronic Kidney Disease. Semin Dial. 2017 May; 30(3):251-61.

85 Teruel-Briones JL, Fernández-Lucas M, Rivera-Gorrin M, Ruiz-Roso G, Díaz-Domínguez M, Rodríguez-Mendiola $\mathrm{N}$, et al. Progression of residual renal function with an increase in dialysis: haemodialysis versus peritoneal dialysis. Nefrologia. 2013;33(5):640-9.

86 Rhee CM, Ahmadi SF, Kovesdy CP, Kalantar-Zadeh K. Low-protein diet for conservative management of chronic kidney disease: a systematic review and meta-analysis of controlled trials. J Cachexia Sarcopenia Muscle. 2018 Apr;9(2):235-45.

87 KDIGO Work Group. KDIGO 2012 clinical practice guideline for the evaluation and management of chronic kidney disease. Kidney Int Suppl. 2013;3(1):1-150.

88 Walser M. Does prolonged protein restriction preceding dialysis lead to protein malnutrition at the onset of dialysis? Kidney Int. 1993 Nov;44(5):1139-44.

89 Aparicio M, Chauveau P, De Précigout V, Bouchet JL, Lasseur C, Combe C. Nutrition and outcome on renal replacement therapy of patients with chronic renal failure treated by a supplemented very low protein diet. J Am Soc Nephrol. 2000 Apr;11(4):708-16.

90 Locatelli F, Del Vecchio L, Aicardi V. Nutritional Issues with Incremental Dialysis: The Role of Low-Protein Diets. Semin Dial. 2017 May;30(3):246-50.

91 Caria S, Cupisti A, Sau G, Bolasco P. The incremental treatment of ESRD: a low-protein diet combined with weekly hemodialysis may be beneficial for selected patients. BMC Nephrol. 2014 Oct;15(1):172.

92 Nakao T, Kanazawa Y, Takahashi T. Once-weekly hemodialysis combined with low-protein and low-salt dietary treatment as a favorable therapeutic modality for selected patients with end-stage renal failure: a prospective observational study in Japanese patients. BMC Nephrol. 2018 Jun;19(1):151.

93 Leavey SF, Strawderman RL, Jones CA, Port FK, Held PJ. Simple nutritional indicators as independent predictors of mortality in hemodialysis patients. Am J Kidney Dis. 1998 Jun;31(6):997-1006.

94 Fouque D, Kalantar-Zadeh K, Kopple J, Cano N, Chauveau P, Cuppari L, et al. A proposed nomenclature and diagnostic criteria for protein-energy wasting in acute and chronic kidney disease. Kidney Int. 2008 Feb; 73(4):391-8.

95 Ikizler TA, Cano NJ, Franch H, Fouque D, Himmelfarb J, Kalantar-Zadeh K, et al.; International Society of Renal Nutrition and Metabolism. Prevention and treatment of protein energy wasting in chronic kidney disease patients: a consensus statement by the International Society of Renal Nutrition and Metabolism. Kidney Int. 2013 Dec;84(6):1096-107.

96 Kopple JD, Monteon FJ, Shaib JK. Effect of energy intake on nitrogen metabolism in nondialyzed patients with chronic renal failure. Kidney Int. 1986 Mar;29(3):734-42.

97 Fouque D, Aparicio M. Eleven reasons to control the protein intake of patients with chronic kidney disease. Nat Clin Pract Nephrol. 2007 Jul;3(7):383-92. 